Jurnal Abdidas Volume 2 Nomor 5 Tahun 2021 Halaman 1240 - 1244

JURNAL ABDIDAS

http://abdidas.org/index.php/abdidas

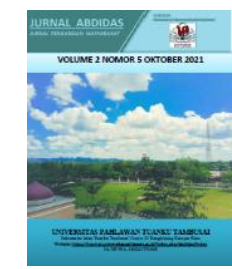

\title{
Strategi Peningkatan Penerimaan Vaksin Covid 19 melalui Health Education di Masyarakat Kota Pekanbaru
}

\author{
Hastuti Marlina ${ }^{1}$, Hetty Ismainar ${ }^{2 \bowtie}$ Hayana $^{3}$ \\ Magister Ilmu Kesehatan Masyarakat, STIKes Hang Tuah Pekanbaru, Riau, Indonesia ${ }^{1,2}$ \\ Kesehatan Masyarakat, STIKes Hang Tuah Pekanbaru, Riau, Indonesia ${ }^{3}$ \\ E-mail: hastutimarlina56@gmail.com ${ }^{1}$, hettyismainar@gmail.com² ${ }^{2}$, hayana.yana1986@gmail.com³
}

\begin{abstract}
Abstrak
Rendahnya minat masyarakat terhadap pelaksanan program vaksin Covid 19 terlihat dari angka cakupan penerima vaksin di Kota Pekanbaru yang belum mencapai target $(<20 \%$, target $>70 \%)$. Berdasarkan temuan dilapangan masih banyak penolakan masyarakat terhadap program vaksinasi. Perlu strategi yang tepat untuk meluruskan persepsi tersebut. Tujuan kegiatan adalah memberikan health education sebagai salah satu strategi peningkatan penerimaan vaksin dimasyarakat. Pemberian health education dengan metode ceramah dan diskusi interaktif. Kegiatan dilaksanakan secara online menggunakan aplikasi google meet. Total 50 peserta warga Desa Pandau Jaya Pekanbaru. Kegiatan berlangsung selama 120 menit. Media edukasi berupa pemutaran video penyataan dari Kemenkes dan epidemiolog melalui youtube dan dialog interaktif dengan dokter Puskesmas. Pengukuran peningkatan pemahaman penerimaan vaksin dilakukan sebelum dan sesudah kegiatan dengan mengisi link google form. Hasil penerimaan vaksin sebelum kegiatan, bersedia 9 orang (18\%) dan belum bersedia 41 orang $(82 \%)$. Setelah kegiatan terjadi peningkatan $52 \%$, peserta yang bersedia 35 orang $(70 \%)$, belum bersedia 15 orang (30\%). Nilai pre-test menunjukkan rata-rata pengetahuan rendah (63\%), sedang $(21,5 \%)$ dan tinggi $(15,5 \%)$. Nilai post-test terjadi peningkatan yang siginifikan yaitu $58 \%$. Pengetahuan rendah $(12,5 \%)$, sedang $(16,5 \%)$ dan tinggi $(73,5 \%)$. Strategi kegiatan pengabdian masyarakat melalui health education dinilai efektif meningkatkan penerimaan vaksin. Perlu tindak lanjut dengan berkoordinasi dengan petugas layanan kesehatan setempat dengan memfasilitasi warga untuk mendapatkan vaksin.
\end{abstract}

Kata kunci: Covid 19, health education, vaksin

\begin{abstract}
The low public interest in the COVID-19 vaccine program can be seen from the total vaccine coverage in Pekanbaru. $(<20 \%$, targets $>70)$. Based on experience, many people reject the vaccination program. We need the right strategy to straighten this perception. This field activity aims to provide health education as a strategy to increase vaccine acceptance in the community. The steps taken are providing health education and interactive dialogue using the google meet application. A total of 50 participants were residents of Pandau Jaya Village, Pekanbaru. Activities were carried out for 120 minutes. The educational media used are youtube videos from the Ministry of Health and epidemiologists. Then interactive dialogue with health workers. Measurement of the increase in receiving of the vaccination program was carried out pre and post by google form. The results were 9 (18\%) receipt COVID-19 vaccines and 41 (82\%), not receipt. After the activity, there was an increase of 52\% in the receipt vaccine program. 35 (70\%), participants who received the COVID-19 vaccine, did not receive 15 (30\%). The pre-test scores showed the average knowledge was low (63\%), moderate $(12.5 \%)$, and high (15.5\%). There was a significant increase in the post-test, namely $58 \%$. Low knowledge $(12.5 \%)$, medium (16.5\%), and high (73.5\%). The strategy of community service activities through health education is considered effective in increasing vaccine receipt. Follow-up is needed by coordinating with local health workers by facilitating residents to get vaccines.
\end{abstract}

Keywords: Covid 19, health education, vaccine

Copyright (c) 2021 Hastuti Marlina, Hetty Ismainar, Hayana

$\triangle$ Corresponding author

Address : J1 Sentosa Gg Sentosa 1 no 69 Tangkerang Labuai Pekanbaru ISSN 2721-9224 (Media Cetak)

Email : hettyismainar@gmail.com

DOI : https://doi.org/10.31004/abdidas.v2i5.426 
1241 Strategi Peningkatan Penerimaan Vaksin Covid 19 Melalui Health Education di Masyarakat Kota Pekanbaru - Hastuti Marlina, Hetty Ismainar, Hayana

DOI : https://doi.org/10.31004/abdidas.v2i5.426

\section{PENDAHULUAN}

Pandemi COVID-19 telah merubah seluruh tatanan dunia kesehatan. Sejak awal diidentifikasi pada bulan Desember 2019 di Wuhan China, banyak negara yang merasakan dampak penyebaran virus ini. Secara global, total yang sudah infeksi Covid-19 hampir 173 juta kasus dan total kematian 3,71 juta jiwa (WHO, 2021).

Berbagai upaya atau strategi telah dilakukan untuk meminimalisir penularan COVID-19. World Health Organization (WHO) mengatakan bahwa seluruh negara menerapkan pembatasan wilayah. Strategi untuk pencegahan makin masif dilakukan diantaranya penggunaan masker, mencuci tangan pakai sabun atau handsanitizer, menjaga jarak, membatasi mobilisasi (WHO, 2020).

Program pencegahan sebagai landasan dibentuknya sebuah tatanan new normal di semua negara. Pencegahan COVID-19 juga telah memasuki tahapan baru dengan tersedianya Vaksin COVID-19 dengan fase uji klinis secara bertahapa dan dapat diproduksi secara massal (Makmun \& Hazhiyah, 2020).

Di Indonesia, total kasus COVID-19 hingga tanggal 5 Januari 2021 mencapai 779.548 kasus dengan jumlah kematian sebanyak 23.109 kasus (Satuan Tugas Penanganan Covid-19 (SATGAS COVID-19), 2021). Salah satu strategi yang dilakukan oleh Pemerintah adalah pemberian vaksinasi secara gratis (Keputusan Menteri Kesehatan, 2021).

Berdasarkan pengalaman, masih banyak ditemukan penolakan masyarakat terhadap pelaksanaan vaksin diseluruh kota di Indonesia termasuk Pekanbaru. Beredar pemberitaan dimasyarakat setelah divaksin ada yang lumpuh dan meninggal. Hal ini membuat masyarakat kembali tidak percaya dengan efikasi vaksin.

Hasil wawancara awal kepada 10 orang warga di RW 24 Desa Pandau Jaya diketahui bahwa 9 orang tidak bersedia di vaksin karena takut lumpuh dan meninggal seperti yang ada di pemberitaan dan 1 orang lainnya masih ada keraguan. Guna mengantisipasi opini tersebut makin melebar maka perlu upaya dan strategi yang tepat agar penerimaan masyarakat terhadap efektifitas dan manfaat vaksin bisa ditingkatkan dengan cara memberikan health eduation kepada masyarakat tentang program vaksinasi dan COVID-19

\section{METODE}

Kegiatan health education ini dilaksanakan secara online menggunakan aplikasi google meet. Total 50 peserta warga Desa Pandau Jaya Pekanbaru. Kegiatan berlangsung selama 120 menit di RW 24 Desa Pandau Jaya, Pekanbaru. Media edukasi berupa pemutaran video penyataan dari Kementerian Kesehatan dan epidemiolog melalui youtube dan dialog interaktif dengan dokter Puskesmas

Kegiatan berlangsung pada hari Sabtu, 20 Maret 2021 Pukul $14 .{ }^{00}-16^{00}$ WIB. Sebelumnya para peserta penyuluhan diberikan penjelasan mengenai penyebaran virus, perilaku pencegahan, efektifitas vaksin, penerimaan fatwa MUI (Majelis Ulama Indonesia).

Pengukuran angka peningkatan pemahaman dan pengetahuan penerimaan vaksin dilakukan sebelum dan sesudah kegiatan dengan mengisi google form yang disebarkan melalui aplikasi whatsapp. Indikator pengukuran pemahaman di nilai dari tingat pengetahuan masyarakat. Hasil tes tersebut dianalisis dengan tabel distribusi frekuensi dengan tingkatan pengetahuan rendah (nilai<56), sedang (nilai 56-75) dan tinggi (nilai >75).

\section{HASIL DAN PEMBAHASAN}

Kegiatan health education secara daring ini diikuti oleh 50 orang warga masyarakat Desa 
1242 Strategi Peningkatan Penerimaan Vaksin Covid 19 Melalui Health Education di Masyarakat Kota Pekanbaru - Hastuti Marlina, Hetty Ismainar, Hayana

DOI : https://doi.org/10.31004/abdidas.v2i5.426

Pandau Jaya. Karakteristik responden mayoritas berusia 31-40 tahun yaitu 21 orang (42\%), usia 2030 berjumlah 16 orang (32\%), sedangkan usia lebih dari 41 tahun yaitu 13 orang (26\%). Berikut dokumentasi pada saat daring (Gambar 1-3).

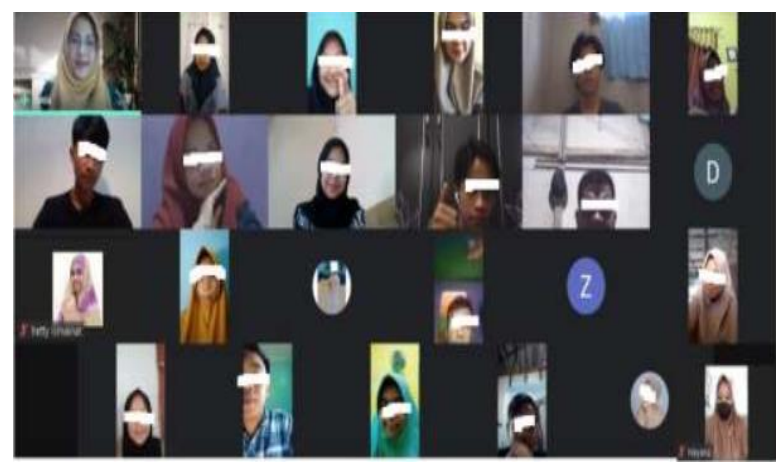

Gambar 1.Dokumentasi health education secara Daring

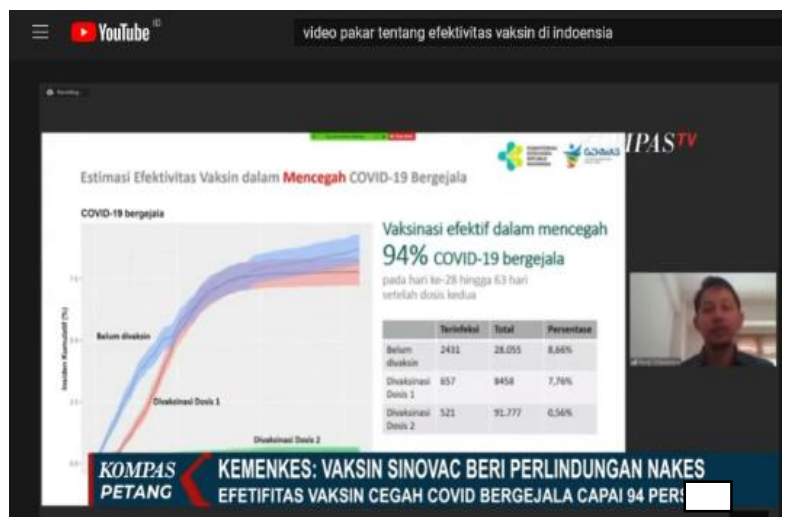

Gambar 2. Pemutaran video youtube dari Kemenkes

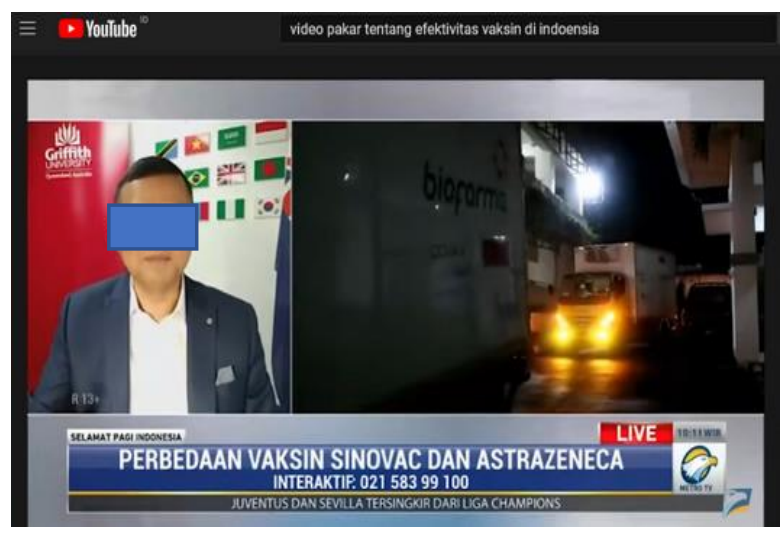

Gambar 3. Pemutaran video youtube dari Epidemiolog

Setelah dilakukan pemutaran video tersebut dilanjutkan dengan pemberian edukasi tentang penyebaran virus, perilaku pencegahan, efektifitas vaksin, penerimaan fatwa MUI (Majelis Ulama Indonesia). Berikut dapat dilihat pada Gambar 4-6.

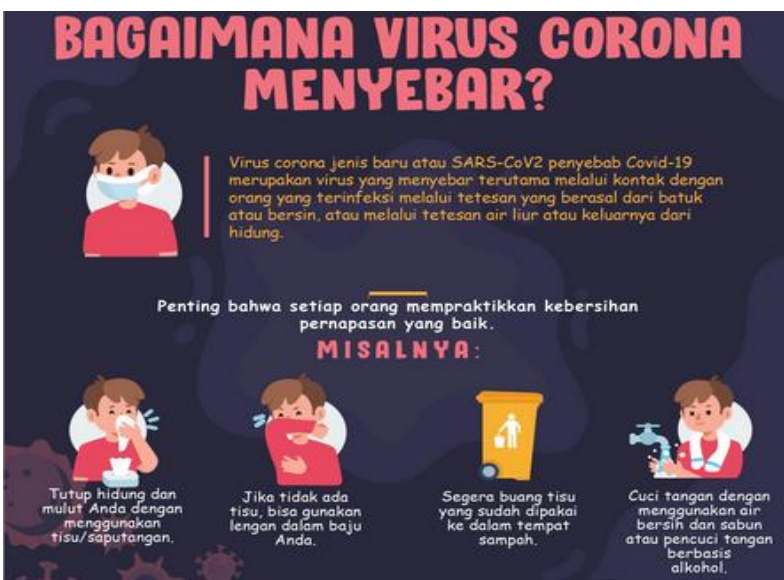

Gambar 4. Cara Penyebaran COVID-19

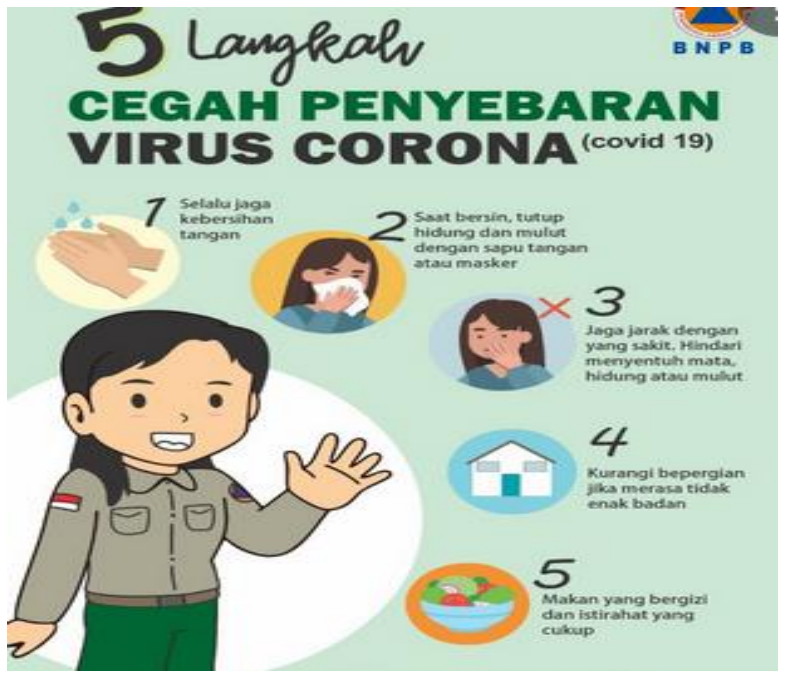

Gambar 5. Perilaku Pencegahan COVID-19

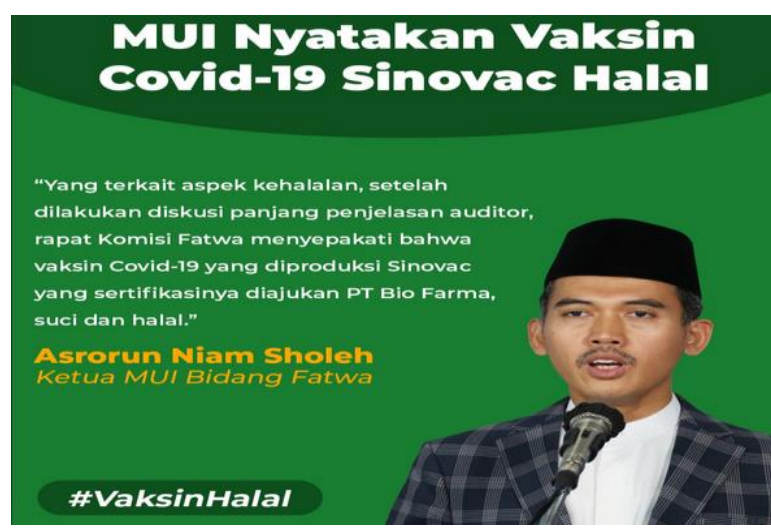

Gambar 6. Fatwa MUI tentang Vaksin Hala

Selama kegiatan berlangsung antusiasme peserta sangat tinggi untuk mengetahui efektifitas vaksin. Hal ini terlihat beberapa pertanyaan yang diajukan peserta secara langsung maupun menuliskan pertanyaan di kolom chat. Nara 
1243 Strategi Peningkatan Penerimaan Vaksin Covid 19 Melalui Health Education di Masyarakat Kota Pekanbaru - Hastuti Marlina, Hetty Ismainar, Hayana

DOI : https://doi.org/10.31004/abdidas.v2i5.426

sumber mendengarkan keluh kesah warga dan menjelaskan kembali dengan jawaban ringkas yang mudah dipahami warga. Nara sumber juga menyampaikan bahwa vaksin tersebut halal dan didukung oleh pernyataan dari MUI (Gambar 6).

Mayoritas penduduk kota Pekanbaru adalah muslim dan religius. Pertanyaan-pertanyaan tersebut selalu menjadi keresahan warga. Setelah mendapatkan penjelasan yang rinci akhirnya warga dapat memahaminya. Hal ini terlihat dari hasil votting yang dikumpulkan sebelum dan sesudah kegiatan. Sebelum kegiatan dimulai data peserta yang belum bersedia vaksin berjumlah 41 orang $(82 \%)$ dan bersedia hanya 9 orang $(18 \%)$. Setelah kegiatan terjadi peningkatan sebesar 52\%. Peserta yang bersedia 35 orang (70\%), belum bersedia 15 orang (30\%). Meski belum 100\% tetapi hal ini cukup memberikan dampak positif. Dari 35 orang (70\%) yang bersedia menerima vaksin 31 orang (62\%) berusia $20-30$ tahun.

Berdasarkan sebuah penelitian di Yordania menyatakan bahwa kelompok usia dewasa (>35 tahun) tingkat penerimaan terhadap vaksin lebih kecil (nilai $\mathrm{p}=0,001)$ dibandingkan usia muda (ElElimat et al., 2021). Sedangkan penelitian lain menyatakan hal yang berbeda bahwa orang yang usianya lebih tua (25-64 tahun), cenderung menerima vaksin daripada kelompok usia muda kurang dari 25 tahun (Lazarus et al., 2020).

Kementerian Kesehatan dan organisasi lainnya (II AGI, UNICEF dan WHO) telah melakukan survey publik terhadap peneriamaa vaksin COVID-19. Ada 115.000 partisipan (34 provinsi di Indonesia). Hasil survey menyatakan ada 658 orang bersedia menerima vaksin, $8 \%$ menolak dan 274 sisanya masih ragu dengan rencana Pemerintah tersebut (Kementerian Kesehatan RI et al., 2020) Masih ada sekitar 7,6 persen masyarakat yang menolak untuk divaksin dan $26,6 \%$ belum memutuskan dan kebingungan (Sukmasih, 2020).

Sebelum kegiatan dilakukan tim telah mengumpulkan data pre-test peserta. Hal ini dilakukan untuk melihat sejauh mana pemahaman partisipan terhadap edukasi yang diberikan ini. Setelah materi selesai juga dilakukan post-test. Hasil dari pre-test dan post-test tersebut tertuang pada tabel 1 dan 2 .

Tabel 1. Hasil Pre-test Pengetahuan Peserta tentang Vaksin

\begin{tabular}{|l|c|c|c|}
\hline \multirow{2}{*}{$\begin{array}{c}\text { Aspek } \\
\text { penilaian }\end{array}$} & \multicolumn{3}{|c|}{ Pengetahuan } \\
\cline { 2 - 4 } & Rendah & Sedang & Tinggi \\
\hline $\begin{array}{l}\text { Penyebaran } \\
\text { virus }\end{array}$ & $28(56 \%)$ & $10(20 \%)$ & $12(24 \%)$ \\
\hline $\begin{array}{l}\text { Perilaku } \\
\text { pencegahan }\end{array}$ & $32(64 \%)$ & $10(20 \%)$ & $8(16 \%)$ \\
\hline $\begin{array}{l}\text { Efektifitas } \\
\text { vaksin }\end{array}$ & $34(68 \%)$ & $11(22 \%)$ & $5(10 \%)$ \\
\hline $\begin{array}{l}\text { Penerimaan } \\
\text { Fatwa MUI }\end{array}$ & $32(64 \%)$ & $12(24 \%)$ & $6(12 \%)$ \\
\hline \multicolumn{1}{|c|}{ Rata-rata } & $63 \%$ & $21,5 \%$ & $15,5 \%$ \\
\hline
\end{tabular}

Tabel 2.Hasil Post-test Pengetahuan tentang Vaksin

\begin{tabular}{|l|c|c|c|}
\hline \multirow{2}{*}{$\begin{array}{c}\text { Aspek } \\
\text { penilaian }\end{array}$} & \multicolumn{3}{|c|}{ Pengetahuan } \\
\cline { 2 - 4 } & Rendah & Sedang & Tinggi \\
\hline $\begin{array}{l}\text { Penyebaran } \\
\text { virus }\end{array}$ & $10(20 \%)$ & $5(10 \%)$ & $35(70 \%)$ \\
\hline $\begin{array}{l}\text { Perilaku } \\
\text { pencegahan }\end{array}$ & $2(4 \%)$ & $10(20 \%)$ & $38(76 \%)$ \\
\hline $\begin{array}{l}\text { Efektifitas } \\
\text { vaksin }\end{array}$ & $8(16 \%)$ & $11(22 \%)$ & $37(74 \%)$ \\
\hline $\begin{array}{l}\text { Penerimaan } \\
\text { Fatwa MUI }\end{array}$ & $5(10 \%)$ & $7(14 \%)$ & $38(76 \%)$ \\
\hline \multicolumn{1}{|c|}{ Rata-rata } & $12,5 \%$ & $16,5 \%$ & $73,5 \%$ \\
\hline
\end{tabular}

Berdasarkan tabel 1 dan 2 terlihat ada peningkatan rata-rata pengetahuan peserta sebanyak 58\%. Pemberian health education dinilai efektif meningkatkan pengetahuan masyarakat tentang COVID-19 dan vaksinasi.

Penelitian di Surabaya menyebutkan bahwa pengetahuan dan kesiapan warga tentang vaksin COVID-19 berada pada kategori baik dan 
1244 Strategi Peningkatan Penerimaan Vaksin Covid 19 Melalui Health Education di Masyarakat Kota Pekanbaru - Hastuti Marlina, Hetty Ismainar, Hayana

DOI : https://doi.org/10.31004/abdidas.v2i5.426

signifikansi $0,000 \quad(\mathrm{p}<0,05) \quad$ sehingga dapat disimpulkan bahwa ada pengaruh pegetahuan terhadap kesediaan vaksinasi (Febriyanti, 2021).

\section{SIMPULAN}

Kegiatan pengabdian masyarakat dalam strategi peningkatan penerimaan vaksin Covid 19 melalui health education dinilai efektif. Setelah kegiatan dilakukan terjadi peningkatan sebanyak $52 \%$ penerimaan masyarakat terhadap program vaksin pemerintah. Sedangkan untuk nilai rata-rata pengetahuan juga mengalami peningkatan sebesar $58 \%$. Perlu tindak lanjut dengan berkoordinasi dengan petugas layanan kesehatan setempat untuk memfasilitasi warga mendapatkan vaksin.

\section{UCAPAN TERIMA KASIH}

Kami berterimakasih kepada pihak yang terlibat yaitu yayasan Hang Tuah Pekanbaru yang telah memberikan dana kegiatan, Prodi Kesmas STIKes Hang Tuah yang telah memberikan izin kegiatan. Seluruh peserta kegiatan warga Desa Pandau Jaya, bapak RT dan RW setempat yang telah berpartisipasi dalam kegiatan ini sehingga dapat berlanjalan dengan baik dan lancar.

\section{DAFTAR PUSTAKA}

El-Elimat, T., Abualsamen, M. M., Almomani, B. A., Al-Sawalha, N. A., \& Alali, F. Q. (2021). Acceptance And Attitudes Toward COVID19 Vaccines: A Cross-Sectional Study From Jordan. Plos ONE, 16(4 April), 1-15. Https://Doi.Org/10.1371/Journal.Pone.02505 55

Febriyanti, Et Al. (2021). Hubungan Tingkat Pengetahuan Dan Kesediaan Vaksinasi Covid-19 Pada Warga Kelurahan Dukuh Menanggal Kota Surabaya. Seminar Nasional Hasil Riset Dan Pengabdian, 3, 1-7. File:///C:/Users/USER/Appdata/Local/Temp/ 168-Article Text-499-1-10-20210424.Pdf

Kementerian Kesehatan RI, UNICEF, \& WHO. (2020). Survei Penerimaan Vaksin COVID$19 D i$ Indonesia. November.
Https://Www.Unicef.Org/Indonesia/Id/Coron avirus/Laporan/Survei-Penerimaan-VaksinCovid-19-Di-Indonesia

Keputusan Menteri Kesehatan. (2021). Keputusan Menteri Kesehatan No. HK.01.07/MENKES/4638/2021 Tentang Petunjuk Teknis Pelaksanaan Vaksinasi Dalam Rangka Penanggulangan Pandemi COVID-19. Keputusan Menteri Kesehatan, 2021, $1-157$.

Https://Www.Dinkes.Pulangpisaukab.Go.Id/ 2021/05/21/Keputusan-Menteri-KesehatanNo-Hk-01-07-Menkes-4638-2021-TentangJuknis-Pelaksanaan-Vaksinasi-DalamRangka-Penanggulangan-Pandemi-Covid-19/

Lazarus, J. V, Ratzan, S. C., \& Palayew, A. (2020). A Global Survey of Potential Acceptance Of A COVID-19 Vaccine.

Makmun, A., \& Hazhiyah, S. F. (2020). Tinjauan Terkait Pengembangan Vaksin COVID 19. Molucca Medica, 13, 52-59.

Satuan Tugas Penanganan Covid-19 (SATGAS COVID-19). (2021). Data Vaksinasi COVID19.

Sukmasih. (2020). Issues, Conflict And Public Opinion. Penerbit Lutfi Gilang. Https://Books.Google.Co.Id/Books?Id=Nxoe eaaaqbaj

WHO. (2020). WHO Indonesia Situation Report-7 Who.Int/Indonesia Situation Report-7. World Health Organization, 2019 (February), 1-16. Https://Jakartaglobe.Id/News/Govt-To-CopyIndia-Strategy-Using-Rapid-Antigen-TestFor-Covid19-

Confirmation\%0Ahttps://Jakartaglobe.Id/Ne ws/Jokowis-New-Fivepoint-PlanAnticipates-Second-Wave-Of-Pandemic

WHO. (2021). Coronavirus Disease 2019 (COVID-19) Coronavirus Coronavirus Disease Disease Situation World Health World Health Organization Organization 28 April 2021. 53, 1-11. Https://Www.Who.Int/Indonesia 